\title{
Cyanobacterial population and harmful metabolites dynamics during a bloom in Yanghe Reservoir, North China
}

\author{
Zonglai $\mathrm{Li}^{\mathrm{a}}$, Jianwei $\mathrm{Yu}^{\mathrm{a}}$, Min Yang ${ }^{\mathrm{a}, *}$, Jing Zhang ${ }^{\mathrm{a}, \mathrm{b}}$, Michael D. Burch ${ }^{\mathrm{c}}$, Wei Han ${ }^{\mathrm{d}}$ \\ a State Key Laboratory of Environmental Aquatic Chemistry, Research Center for Eco-Environmental Sciences, Chinese Academy of Sciences, 18 Shuangqing Road, \\ Haidian District, Beijing 100085, China \\ ${ }^{\mathrm{b}}$ Beijing Center for Disease Prevention and Control, Beijing 100013, China \\ ${ }^{\mathrm{c}}$ Australian Water Quality Centre, Adelaide, SA 5001, Australia \\ d Beijing Capital Co. Ltd., Beijing 100028, China
}

\section{A R T I C L E I N F O}

\section{Article history:}

Received 6 December 2008

Received in revised form 12 March 2010

Accepted 12 March 2010

\section{Keywords:}

Anabaena spiroides

Anatoxin-a

Cyanobacterial bloom

Geosmin

Microcystin

Microcystis

\begin{abstract}
A B S T R A C T
A significant outbreak of odorous and toxic cyanobacteria occurred in Yanghe Reservoir, North China, in the summer of 2007. The dominant species was Anabaena spiroides and it was accompanied with the occurrence of very high concentrations of the odor metabolite geosmin. The event included two cycles of growth of $A$. spiroides: the first one of approximately 16 days between 21 June and 8 July, with the peak density 70,000 cells $\mathrm{mL}^{-1}$ on 2 July, and the second smaller bloom of over 50 days between 9 July and the end of August. The bloom also included a range of species of Microcystis, predominantly M. aeruginosa, as the second largest population, which varied from 5800 cells $\mathrm{mL}^{-1}$ to 28,000 cells $\mathrm{mL}^{-1}$ in the first cycle and from 2000 cells $\mathrm{mL}^{-1}$ to 11,000 cells $\mathrm{mL}^{-1}$ in the second. Geosmin reached the peak value of $7100 \mathrm{ng} \mathrm{L}^{-1}$ on $3 \mathrm{July}$, which was the highest value ever reported. The average geosmin production potential for $A$. spiroides cells was approximately $0.1 \mathrm{pg} \mathrm{cell}^{-1}$, which was also very high and $85-97 \%$ of geosmin was found within the cells and in addition the dissolved geosmin did not increase even during the cyanobacterial decay period. In addition to odor metabolites, three microcystin variants MC-LR, MCRR, MC-YR and anatoxin-a, most of which were intracellular, were detected, with MC-RR being the dominant cyanotoxin. The highest cyanotoxin concentrations were: dissolved: MC-RR $1.56 \mu \mathrm{g} \mathrm{L}^{-1}$, MCYR $0.066 \mu \mathrm{g} \mathrm{L}^{-1}$, MC-LR $0.544 \mu \mathrm{g} \mathrm{L}^{-1}$, anatoxin-a $0.106 \mu \mathrm{g} \mathrm{L}^{-1}$; intracellular: MC-RR $70.1 \mu \mathrm{g} \mathrm{L}^{-1}$, MC-YR $3.76 \mu \mathrm{g} \mathrm{L}^{-1}$, MC-LR $24.6 \mu \mathrm{g} \mathrm{L}^{-1}$, anatoxin-a $0.184 \mu \mathrm{g} \mathrm{L}^{-1}$, and these occurred on 2 July. The correlation between geosmin and $A$. spiroides was excellent $\left(R^{2}=0.912\right)$, however the correlation between anatoxina concentrations and Anabaena densities and between MCs concentrations and Microcystis densities was not as strong. This study demonstrated the relatively complex requirement for monitoring cyanobacterial blooms in this lake in China, where both the range of odors and cyanotoxins can be produced in concentrations which can change rapidly over a short time along with the bloom composition. It also demonstrated that both odor compounds and cyanotoxins should be considered in terms of the potential hazard to public water supply when a bloom was dominated by Anabaena and Microcystis occurs.
\end{abstract}

( 2010 Elsevier B.V. All rights reserved.

\section{Introduction}

Cyanobacterial blooms have become more intensive worldwide during the last two decades, due to the increasing anthropogenic inputs of nitrogen and phosphorus to water environments (Paerl et

\footnotetext{
* Corresponding author at: P.O. Box 2871, Beijing 100085, China. Tel.: +8610 62923475; fax: +861062923475.

E-mail addresses: lizonglai@gmail.com (Z. Li), jwyu@rcees.ac.cn (J. Yu), yangmin@rcees.ac.cn (M. Yang), brightjing@163.com (J. Zhang), mike.burch@sawater.com.au (M.D. Burch), hanwei@beijingcaptial.com.cn (W. Han).
}

al., 2001; Khan and Ansari, 2005). In addition to the aesthetic and ecological problems, cyanobacterial blooms can have serious consequences for drinking water supply by physically blocking the filtration processes in water treatment plants, and producing a range of metabolites such as harmful cyanotoxins and taste and odor (T/O) compounds (Watson, 2004; van Apeldoorn et al., 2007; Watson et al., 2007).

Microcystis, which is the most frequently reported cyanobacterial genus responsible for freshwater cyanobacterial blooms worldwide (Haider et al., 2003), has long been a primary focus of attention because of its potential to produce microcystins (MCs), a group of cyclic heptapeptide hepatotoxins with more than 60 
variants (Duy et al., 2000). The Microcystis-dominated cyanobacterial blooms frequently occur in shallow lakes in tropical and subtropical regions with adequate nutrient supply, high temperature and high water stability usually associated with stratified conditions (Neilan et al., 1994; Sedmak and Kosi, 1998; Dokulil and Teubner, 2000; Xie et al., 2003; Yoshinaga et al., 2006; Xu Y. et al., 2008). Anabaena, which is another significant bloom-forming cyanobacterial genus, is well known for its ability to produce geosmin, a taste/odor (T/O) compound with earthy or moldy smell (Izaguirre et al., 1982; Hayes and Burch, 1989; Saadoun et al., 2001; Tsujimura and Okubo, 2003; Wang et al., 2005). In addition, Anabaena has recently been identified as a producer of anatoxin-a, a potent postsynaptic depolarizing neuromuscular blocking cyanotoxin (Beltran and Neilan, 2000; Pawlik-Skowronska et al., 2004; Osswald et al., 2007) as well as MCs (Sotero-Santos et al., 2008). Although Anabaena is a common bloom-forming cyanobacterium with a worldwide distribution, there are few reported studies of the occurrence of Anabaena and the associated metabolites geosmin and cyanotoxins worldwide.

There have however been several studies of the production of odorous and toxic metabolites by cyanobacteria in well-known eutrophic lakes in southern China. These have included the dynamics of odorous metabolites in Dianchi Lake (Li L. et al., 2007), and seasonal variation of microcystin in Taihu Lake (Shen et al., 2003; Xu Q. et al., 2008). All of these studies have monitored the lakes at monthly intervals and did not capture the dynamic variability in the cyanobacterial population growth cycle of individual species.

In addition there have been no studies of cyanobacterial blooms in China with mixed or co-dominant species that concurrently produce both cyanotoxins and odorous metabolites. The production of both cyanotoxins and odorous metabolites at the same time will present an interesting challenge for the management of blooms and the selection of treatment options to properly ensure the safety of drinking water supplies.

Yanghe Reservoir is an important water source for Qinhuangdao City in north China, and has been known for the occurrence of major cyanobacterial blooms in early summer in recent years (Li W. et al., 2007). Significant earthy geosmin-like odors in water supply have been reported to be associated with these blooms. The current study reports an intensive 2 -month investigation from late June 2007 to track the cyanobacterial population and the metabolites in Yanghe Reservoir at short-time intervals to investigate the bloom dynamics in a mixed odor and toxinproducing population over the summer bloom season. The study was initiated to assess the relative production and dynamic variation of the range of compounds and assess the threat to drinking water treatment for the treatment works associated with Yanghe Reservoir.

\section{Materials and methods}

\subsection{Sampling}

Yanghe Reservoir has a capacity of $3.58 \times 10^{8} \mathrm{~m}^{3}$, an average depth of $5.7 \mathrm{~m}$, average water area of $13 \mathrm{~km}^{2}$, and volume of $0.75 \times 10^{8} \mathrm{~m}^{3}$ during the period of the investigation. Source water was taken from the water intake as shown in Fig. 1, and supplied to four waterworks in Qinhuangdao City through a $30 \mathrm{~km}$ long pipeline. Samples were taken daily from the water intake area $\left(119^{\circ} 12^{\prime} 51^{\prime \prime} \mathrm{E}, 39^{\circ} 58^{\prime} 51^{\prime \prime} \mathrm{N}\right)$ from 25 June to 24 August 2007. Surface layer samples were collected in polypropylene bottles from a depth of $0.1-0.5 \mathrm{~m}$, and transported immediately to the laboratory in the city for analysis or pretreatment. Cyanobacterial cells were counted under the microscope within $1 \mathrm{~h}$ of arrival at the laboratory, and samples for cyanotoxin analysis were
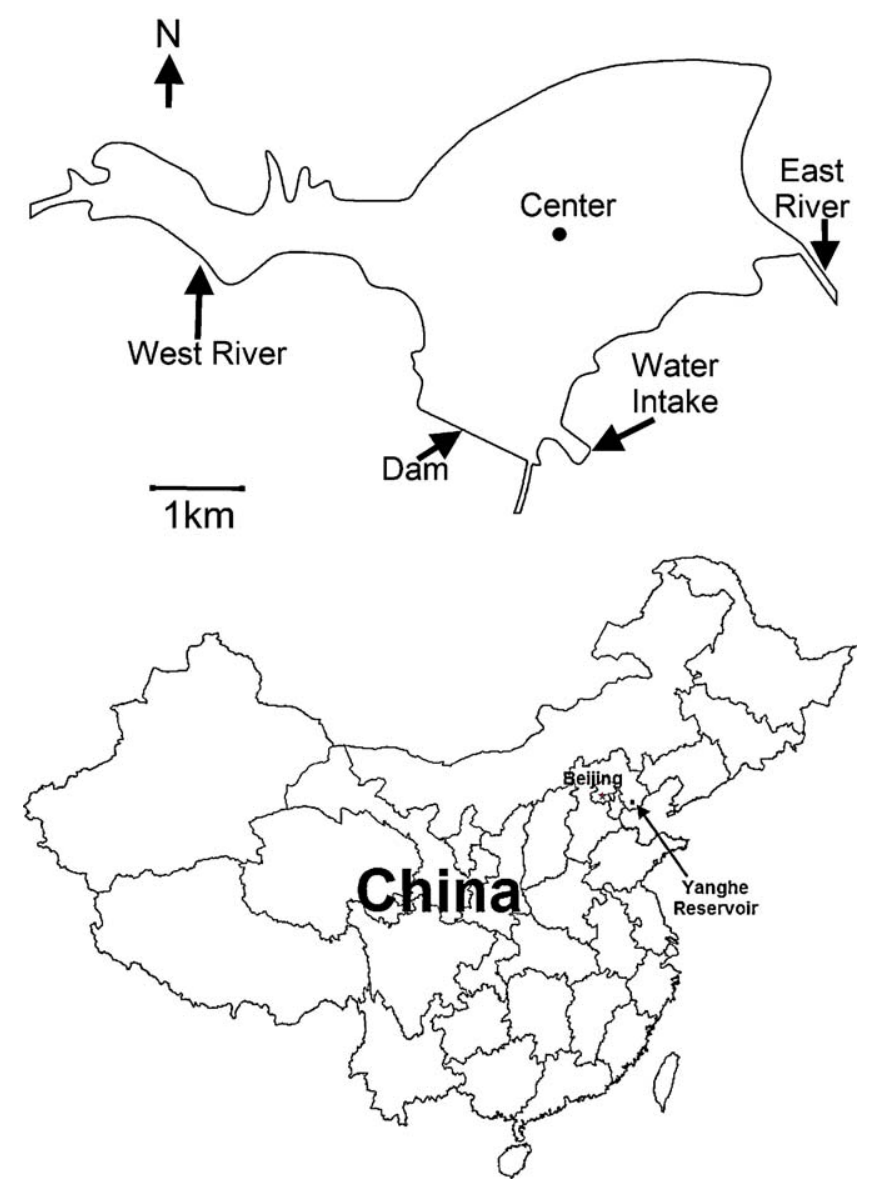

Fig. 1. Schematic map of Yanghe Reservoir and its geographical position in China, main sample site was the water intake.

pretreated within $2 \mathrm{~h}$. If the samples could not be analyzed immediately, they were stored under refrigeration at $4{ }^{\circ} \mathrm{C}$. The samples for odor compounds determination were stored in brown glass bottles with airtight stopper at $4{ }^{\circ} \mathrm{C}$ and analyzed as soon as possible, after $10 \mathrm{mg} \mathrm{L}^{-1} \mathrm{HgCl}_{2}$ was added to prevent biodegradation (American Public Heath Association, 2001).

\subsection{Chemicals and reagents}

All chemicals and solvents were of analytical or HPLC grade. Geosmin, MIB, 2-isobutyl-3-methoxy-pyrazine (IBMP) and 2isopropyl-3-methoxy-pyrazine (IPMP) standards were obtained from Acros Organics, Belgium. Anatoxin-a, microcystin LR, RR, YR standards were bought from Alexis Company, Switzerland. HPLC grade methanol, acetonitrile (ACN) and formic acid were products of Fisher, USA. $\mathrm{NaCl}, \mathrm{KI}, \mathrm{I}_{2}, \mathrm{HgCl}_{2}$ of analytical grade were from Beijing Chemicals Ltd.

\subsection{Cyanobacterial cell counting}

Cyanobacterial cell number was counted with a $0.1 \mathrm{~mL}$ phytoplankton counter chamber (HL-JS 0 Wuhan Hengling Ltd., China) using a microscope (Zeiss Axioskop 2 Mot Plus, Germany). For the samples with a high cell density, cell numbers were counted without concentration. For other samples, cell numbers were counted after preconcentration of $10 \times$ (from $100 \mathrm{~mL}$ to $10 \mathrm{~mL}$ ) by settling in Lugol's solution.

The samples were dominated mainly by Anabaena spiroides and several species of Microcystis. The cell number of the Microcystis species, which is a colonial aggregation of individual cells, was 
Table 1

Mass spectrometry parameters.

\begin{tabular}{|c|c|c|c|c|c|c|}
\hline Toxin & Retention time (min) & Precursor ion $\mathrm{m} / \mathrm{z}$ & Product ion $m / z$ & Product ion $m / z$ & Cone voltage (V) & Collision energy (V) \\
\hline Anatoxin-a & 1.480 & 166.1 & 148.8 & 130.6 & 35 & 15 \\
\hline MC-RR & 2.525 & 520.1 & 135.2 & 887.7 & 45 & 20 \\
\hline MC-YR & 2.660 & 1045.8 & 213.1 & 375.5 & 75 & 55 \\
\hline MC-LR & 2.750 & 995.8 & 135 & 213.4 & 75 & 55 \\
\hline
\end{tabular}

estimated by judging the individual colony volume and dividing by the average single-cell volume for the different species (Hötzel and Croome, 1999). For A. spiroides, the coiled filamentous cyanobacteria, the average cell number of individual spiral coils was obtained under $40 \times$ objective lens, and then the coil number was counted under $10 \times$ objective lens, and the cell density was determined by multiplying the coil number with the average cell number of one coil. Cyanobacterial microscopic photos were taken under the bright field (BF) mode or the differential interference contrast (DIC) mode.

\subsection{Analysis of odor compounds}

\subsubsection{SPME procedure}

The headspace solid phase micro-extraction (HS-SPME) method (Liang et al., 2005) was employed for the extraction of odor compounds with a DVB/CAR/PDMS fiber (57348-U, Seplco, America). Briefly, after $12.5 \mathrm{~g} \mathrm{NaCl}$ and $20 \mu \mathrm{L}$ internal standard solution containing IBMP $50 \mu \mathrm{g} \mathrm{L}^{-1}$ and IPMP $50 \mu \mathrm{g} \mathrm{L}^{-1}$ were added in a $75 \mathrm{~mL}$ vial containing $50 \mathrm{~mL}$ water samples, the vial was then sealed with a silicone-teflon septum cap inserted with the extraction fiber, and put into a $65^{\circ} \mathrm{C}$ water bath shaken at $800 \mathrm{rpm}$. After a 30 min headspace extraction, the fiber was taken out from cap and immediately inserted into the GC injection port to desorb for $3 \mathrm{~min}$ at $240{ }^{\circ} \mathrm{C}$. Dissolved odor compounds were determined by using the same procedure after the samples were first filtered through GF/C (Whatman, England, $1.2 \mu \mathrm{m}$ ) filters to remove cyanobacterial cells.

\subsubsection{GC-MS analysis}

The GC-MS analysis was based on the method developed by Liang et al. (2005). Analysis was carried out in an Agilent 6890/ 5975 GC-MS system with a $30 \mathrm{~m}$ HP-5 ms capillary column (i.d. $0.25 \mathrm{~mm}$, coating film thickness $0.25 \mu \mathrm{m}$ ). In scan mode, oven temperature was held at $40{ }^{\circ} \mathrm{C}$ for $3 \mathrm{~min}$, raised to $200{ }^{\circ} \mathrm{C}$ at $4{ }^{\circ} \mathrm{C} \min ^{-1}$ and maintained at this temperature for $2 \mathrm{~min}$, then raised to $260{ }^{\circ} \mathrm{C}$ at $15^{\circ} \mathrm{C} \mathrm{min}^{-1}$, and kept at $260{ }^{\circ} \mathrm{C}$ for $2 \mathrm{~min}$. The scan ion range $m / z$ was $46-260$. In quantitative select ion mode (SIM), oven temperature was raised from $40{ }^{\circ} \mathrm{C}$ to $240{ }^{\circ} \mathrm{C}$ at $8{ }^{\circ} \mathrm{C} \mathrm{min}^{-1}$ and maintained at this temperature for $5 \mathrm{~min}$. The transfer-line temperature was $280^{\circ} \mathrm{C}$ and ion-trap temperature was $230{ }^{\circ} \mathrm{C}$. The ion-trap mass spectrometer was operated in the EI positive mode $(70 \mathrm{eV})$. The quantitative ions $(\mathrm{m} / \mathrm{z})$ selected for geosmin, IBMP and IPMP were 112, 124 and 137, respectively. Geosmin concentrations were determined by calibrating with the relative response factor (RRF) of IBMP and IPMP.

\subsection{Cyanotoxins analyses}

\subsubsection{Sample pretreatment}

Water samples (2L) were filtered through a GF/C filter to remove cyanobacteria after the $\mathrm{pH}$ was adjusted to 5.0 with $1 \mathrm{~mol} \mathrm{~L}^{-1} \mathrm{HCl}$. The filtrates were used for the determination of dissolved toxins, and the cyanobacterial cells remaining on the GF/ $C$ filters were used for measurement of intracellular cyanotoxins. A solid phase extraction (SPE) procedure (Aranda-Rodriguez et al., 2003) was used for concentration of toxins with a little modification, which involved activation of the cartridge (Oasis ${ }^{\circledR}$ HLB $500 \mathrm{mg}$, Waters, America) with $10 \mathrm{~mL}$ of methanol, conditioning with $10 \mathrm{~mL}$ of distilled water, and percolation of the sample at a flow rate of $10 \mathrm{~mL} \mathrm{~min}{ }^{-1}$. After a drying procedure of successive centrifugation and evaporation under a gentle stream of nitrogen, the cartridges were washed with $10 \mathrm{~mL} 40 \%$ methanol and eluted with $10 \mathrm{~mL}$ of $80 \%$ methanol slowly (Zhang et al., 2005). The elution was concentrated to a final volume of $1 \mathrm{~mL}$ by evaporation under a gentle stream of nitrogen. The extracted samples were filtered with $0.2 \mu \mathrm{m}$ disposable nylon membrane before injection.

For the determination of intracellular cyanotoxins, the above GF/ C filters were put into a $22 \mathrm{~mL}$ glass vial containing $10 \mathrm{~mL}$ of $80 \%$ methanol. Cell lysis was conducted in an ultrasonic cell crusher for $10 \mathrm{~min}$ ( $10 \mathrm{~s}-10 \mathrm{~s}$ pulse, $500 \mathrm{~W}$ ). The solutions were then treated using the same procedure as for the dissolved toxins after centrifugation $(8000 \times \mathrm{g}, 10 \mathrm{~min})$ and filtration with $\mathrm{GF} / \mathrm{C}$ filters.

\subsubsection{HPLC-MS/MS parameters}

The HPLC-MS/MS system consists of Waters Acquity UPLC ${ }^{\mathrm{TM}}$ equipment (Waters, Milford, USA), an Acquity UPLC ${ }^{\mathrm{TM}}$ BEH C18 column $(100 \mathrm{~mm} \times 2.1 \mathrm{~mm}, 1.7 \mu \mathrm{m})$ and a Quattro Ultima ${ }^{\mathrm{TM}} \mathrm{Pt}$ Mass system. The column oven was set at $40{ }^{\circ} \mathrm{C}$ with a mobile phase flow of $0.3 \mathrm{~mL} \mathrm{~min}^{-1}$. The mobile phase consisted of ACN and water with $0.1 \%(\mathrm{v} / \mathrm{v})$ formic acid. The injection volume was $5 \mu \mathrm{L}$. The mass spectrometer used was operated in ESI positive mode with a capillary voltage of $3.0 \mathrm{kV}$ and multiplier voltage of $650 \mathrm{~V}$. The cone voltages are listed in Table 1 . The nebulizing gas was adjusted to the maximum and desolvation gas at a flow rate of $450 \mathrm{~L} \mathrm{~h}^{-1}$. Cone gas was not used. The source and desolvation temperatures were held at $100^{\circ} \mathrm{C}$ and $350{ }^{\circ} \mathrm{C}$, respectively. UHP argon was used as the collision gas, and the pressure of the collision chamber was held at $3.3 \times 10^{3}$ mbar. Conditions for mass spectrometry are shown in Table 1 .

\subsection{Water quality and other environmental parameters}

All of the water quality analyses were performed according to standard examination methods for drinking water (GB/T 57502006). The $\mathrm{pH}$, ammonia nitrogen and permanganate index were analyzed daily, and other parameters determined occasionally. The temperature and rainfall information was kindly provided by local weather bureau (Fig. 2).

\section{Results and discussion}

\subsection{Cyanobacterial bloom outbreak}

The cyanobacterial bloom first appeared and was associated with strong earthy smell in Yanghe Reservoir from 20 June. Cyanobacterial scum appeared in the water surface layer near the bank and was concentrated by wind and waves. The cyanobacterial population consisted mainly of several Microcystis species and A. spiroides as dominants (Fig. 3), while the phytoplankton community had sporadic occurrence of a range of other cyanobacterial and algal types including Oscillatoria sp., Melosira varians, Asterionella formosa, Cyclotella sp., Fragilaria crotonensis, 


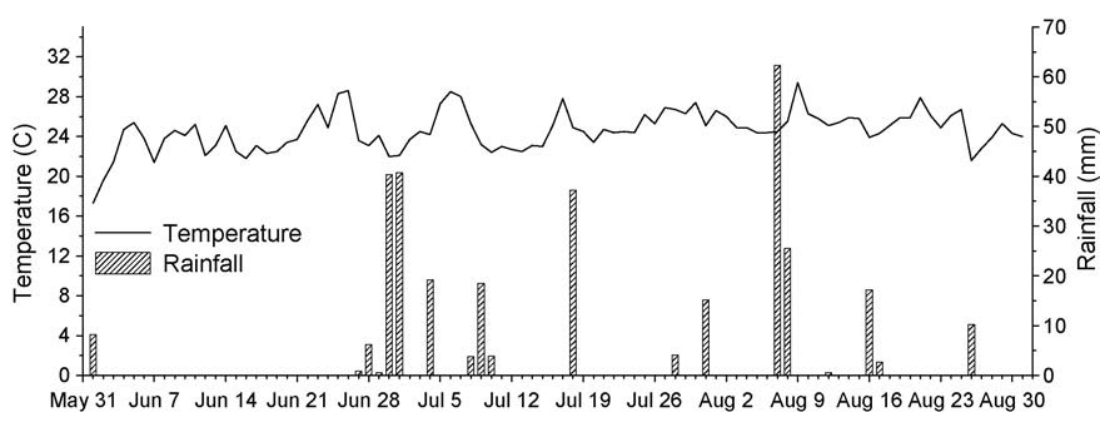

Fig. 2. Temperature and rainfall at Yanghe Reservoir from June to August 2007.

Synedra acus, Pediastrum simple, Chlorella sp., Ceratium hirundinella and Volvox sp. The Microcystis population in Yanghe Reservoir was comprised predominantly of Microcystis aeruginosa, which is the most common microcystin producer and bloom-forming cyanobacterium (Moore et al., 1993; Codd, 1995). Other Microcystis species (10-30\%) present included $M$. wesenbergii, M. novacekii, and M. botrys. A. spiroides, which has been shown to produce geosmin, anatoxin-a and MCs (Van der Ploeg et al., 1992; Velzeboer et al., 2000; Pawlik-Skowronska et al., 2004) was the only Anabaena species present in the reservoir.

As shown in Fig. 2, it had been fine weather with a temperature varying between $22^{\circ} \mathrm{C}$ and $26^{\circ} \mathrm{C}$ for 20 days with no rainfall before the occurrence of the cyanobacterial bloom. Other conditions were as follows: total nitrogen (TN): $3-7 \mathrm{mg} \mathrm{L}^{-1}$, total phosphorus (TP): 0.04-0.08 $\mathrm{mg} \mathrm{L}^{-1}, \mathrm{pH}: 8-9$, and dissolved oxygen: $3-9 \mathrm{mg} \mathrm{L}^{-1}$, Permanganate index: $3.3-12.2 \mathrm{mg} \mathrm{L}^{-1}$.

\subsection{Cyanobacterial population dynamics}

The variation in cell densities of Microcystis spp. and A. spiroides at the water intake during the investigation period is shown in
Fig. 4. It is clear that the growth dynamics of the cyanobacterial population could be divided into two cycles over the summer. The first cycle of rapid growth and decline was of approximately 20 days from 20 June to 9 July, and the second of approximately 40 days started from 10 July. The $A$. spiroides population showed very rapid growth and decay rates in the first cycle: the cell density increased from 500 cells $\mathrm{mL}^{-1}$ on 20 June to the maximum value of 70,000 cells $\mathrm{mL}^{-1}$ on 2 July, replacing Microcystis spp. as the dominant cyanobacterium, and then declined rapidly to the minimum level of 1000 cells $\mathrm{mL}^{-1}$ on 9 July. The cell density of Microcystis spp., on the other hand, did not change as much, only varying in the range of $1800-28,000$ cells $\mathrm{mL}^{-1}$.

A slow increase and decrease of $A$. spiroides cell density with a much lower peak value $\left(19,300\right.$ cells $\left.\mathrm{mL}^{-1}\right)$ were observed in the second cycle. The cell densities of Microcystis spp. were relatively stable and $A$. spiroides was again the dominant cyanobacteria throughout most of this period. From 10 August $A$. spiroides began to decline and Microcystis spp. became the dominant species for a short period. Also at this same time, the algal population diversity increased with the appearance of diatoms including $F$. crotonensis and S. acus.

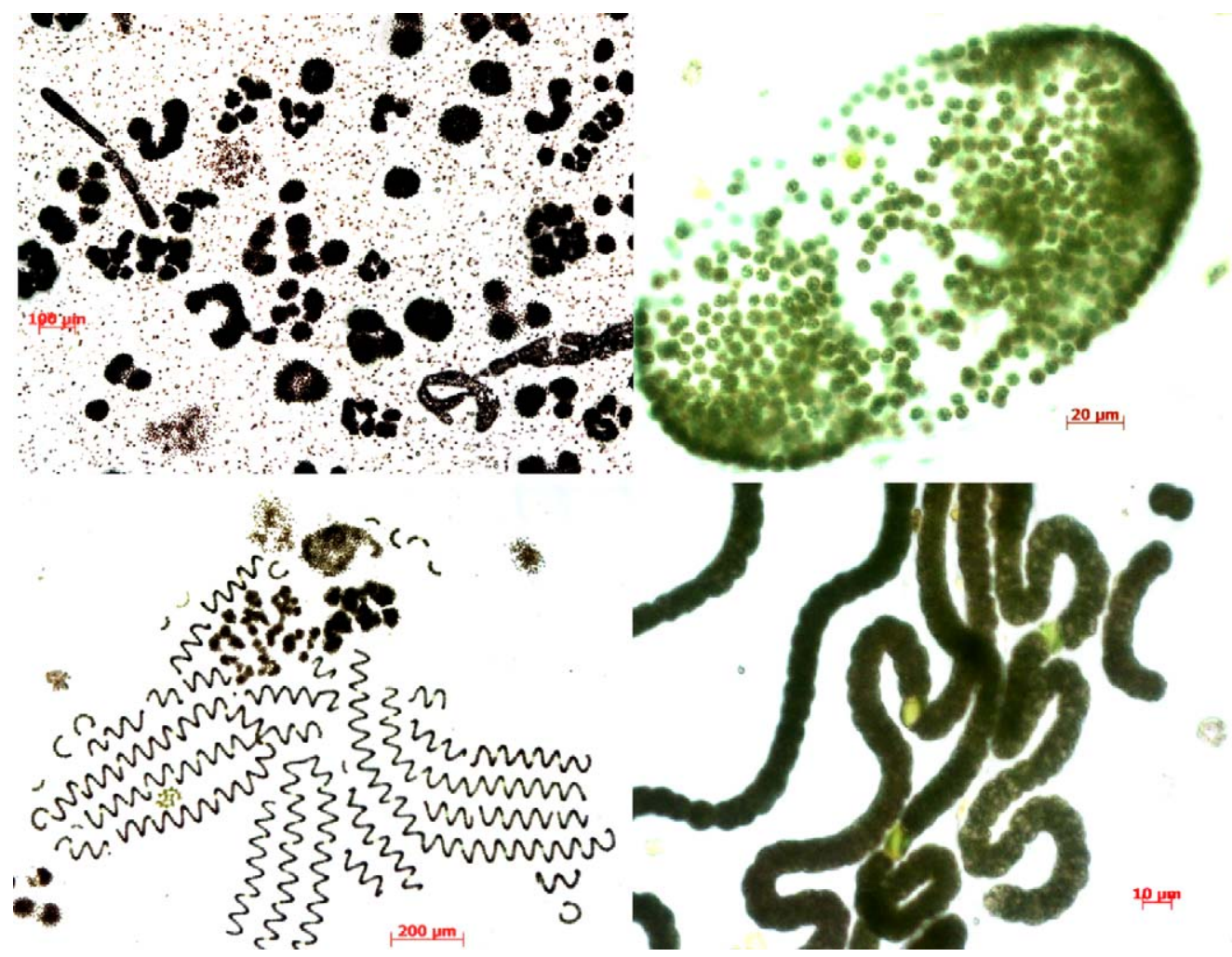

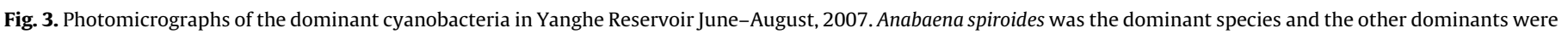
a mixed population of Microcystis spp. which consisted primarily of M. aeruginosa, with smaller contributions from M. wesenbergii, M. novacekii, and M. botrys. 


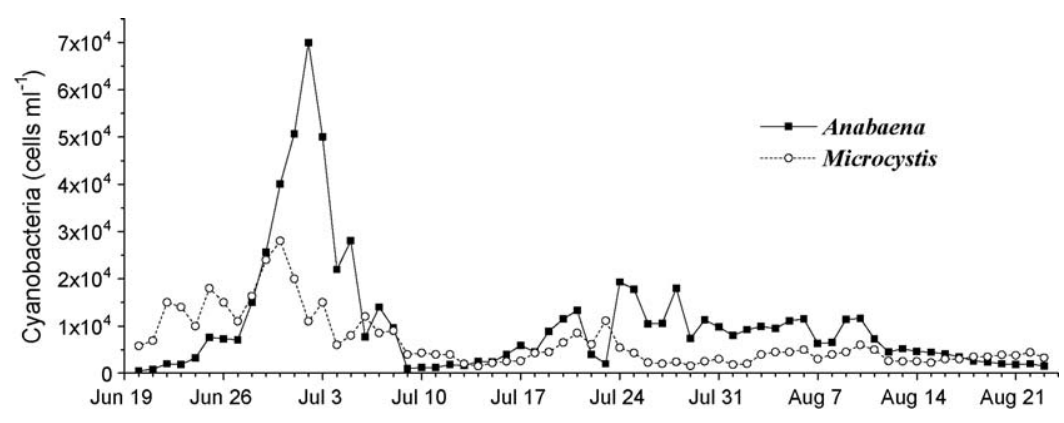

Fig. 4. Cyanobacterial population dynamics of the dominant genera in the water intake.

The possible reasons for lower peak cyanobacteria biomass during the second cycle as opposed to the first is not known, however it may relate to nutrient availability as much of the nutrition assimilated by cyanobacterial cells during the first cycle may have sedimented with the collapse of the population and had not remineralised from the sediments to become bioavailable for the latter period of growth.

Gray foam and scum appeared on the water surface between 6 July and 10 July, which was associated with the appearance of Volvox sp. ( 3300 cells $\mathrm{mL}^{-1}$ on 6 July). This scum vanished suddenly together with Volvox sp. The organic matter might be responsible for the growth of Volvox sp. (Gladyshev et al., 1998). It was observed that the permanganate index increased from 3.18$4.60 \mathrm{mg} \mathrm{L}^{-1}$ (June 25-1 July, average $3.78 \mathrm{mg} \mathrm{L}^{-1}$ ) to $5.4-$ $12.2 \mathrm{mg} \mathrm{L}^{-1}$ (July 2-July 8 , average $8.54 \mathrm{mg} \mathrm{L}^{-1}$ ), and then decreased to approximately $4 \mathrm{mg} \mathrm{L}^{-1}$. The organic matter increase may be as a result of decomposition of massive dead cyanobacterial cells after the peak.

The rapid growth and then sharp decline of the cyanobacterial population in Yanghe Reservoir are intriguing. The numbers of cyanobacteria in particular collapsed from the maximum value of 81,000 cells $\mathrm{mL}^{-1}$ to 28,000 cells $\mathrm{mL}^{-1}$ in 2 days then continued to decrease gradually to reach the lowest value of 3600 cells $\mathrm{mL}^{-1}$ on 13 July. Although the trigger for this sharp decline is unclear, it is possible to speculate about possible causes as follows: (1) bioavailable nutrients had been depleted; (2) rain event (approximately $90 \mathrm{~mm}$ ) in June 30 and July 1 (Fig. 2) resulted a major local run-off which flowed into Yanghe Reservoir and caused water turbulence. Cyanobacteria are favored by a stable water column and turbulence may impact the relatively fragile cell wall of cells such as Anabaena; (3) aging of the cyanobacterial population and cell death (apoptosis) can contribute to the decline of a bloom (Bidle and Falkowski, 2004; Veldhuis and Brussaard, 2006); (4) dissolved oxygen depletion and stress at high cell densities due to a reduction in photosynthesis and also increased biological oxygen

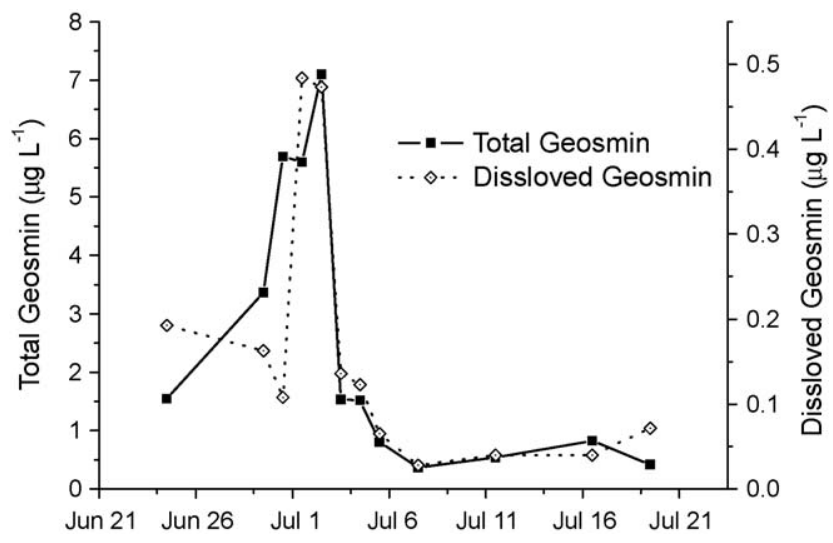

Fig. 5. Geosmin variation in the water intake surface layer. demand due to microbial processes in the sediments and water column as a result of the bloom; (5) other biotic effects such as grazing by protozoans or zooplankton, lytic bacteria or viruses that can infect cyanobacteria.

\subsection{Variation of odorous compounds}

Analysis of major odorous compounds was performed by GC/ MS analysis under scan mode. The most abundant cyanobacteriarelated compounds were geosmin and $\beta$-cyclocitral, together with others such as $\beta$-ionone, camphor, hexanal, octanol, nonanal, 5hepten-2-one, nonanol, DL-menthol, etc., present at a much lower level. The odor of $\beta$-cyclocitral is described as tobacco or smoky with an OTC (odor threshold concentrations) of $19.3 \mu \mathrm{g} \mathrm{L}^{-1}$, while the odor of geosmin is described as earthy or musty with a lower OTC (4 ng L ${ }^{-1}$ ) (Watson, 2004). Based upon the significant occurrence of geosmin and the association with $A$. spiroides, it was likely that geosmin was mainly responsible for the heavy musty odor of source water reported throughout the period of the investigation.

Total geosmin concentration in the water intake is shown in Fig. 5. The variation in geosmin was closely related to the cell density of $A$. spiroides (Fig. 4), further suggesting that geosmin produced by $A$. spiroides was responsible for the odor in the reservoir. Total geosmin level increased rapidly with a 1-2-day lag behind the increase in $A$. spiroides cell density, and dropped equally quickly with the decrease of cell density. The maximum geosmin concentration of $7100 \mathrm{ng} \mathrm{L}^{-1}$ was observed on 3 July, 1 day after $A$. spiroides reached its maximum cell density. This is one of the highest geosmin levels ever reported. Previously, $4000 \mathrm{ng} \mathrm{L}^{-1}$ in Australia (Jones and Korth, 1995) and $3170 \mathrm{ng} \mathrm{L}^{-1}$, in South Africa (Wnorowski and Scott, 1992) have been reported in natural waters.

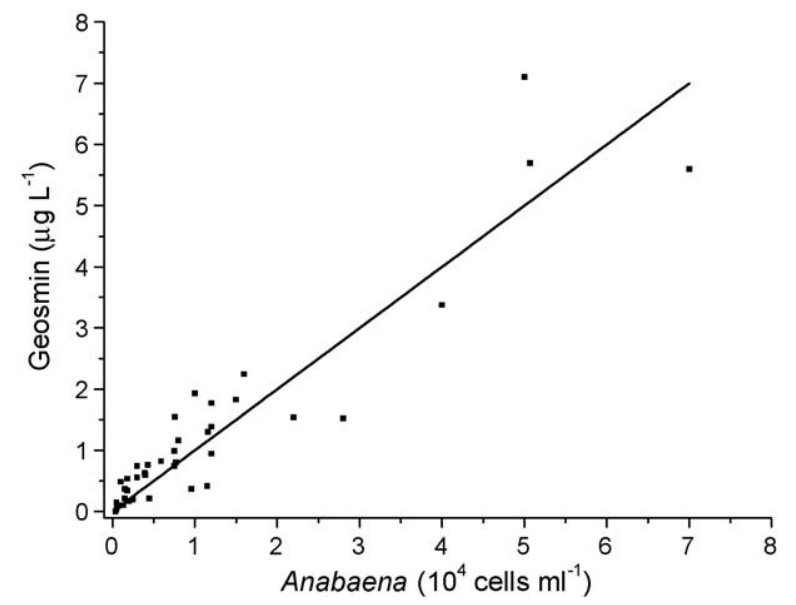

Fig. 6. Correlation of geosmin concentration with Anabaena spiroides density, $n=40$. $Y=0.999 \times X \approx 1 \times X$; slope standard error $=0.049 ; R^{2}=0.912$. 


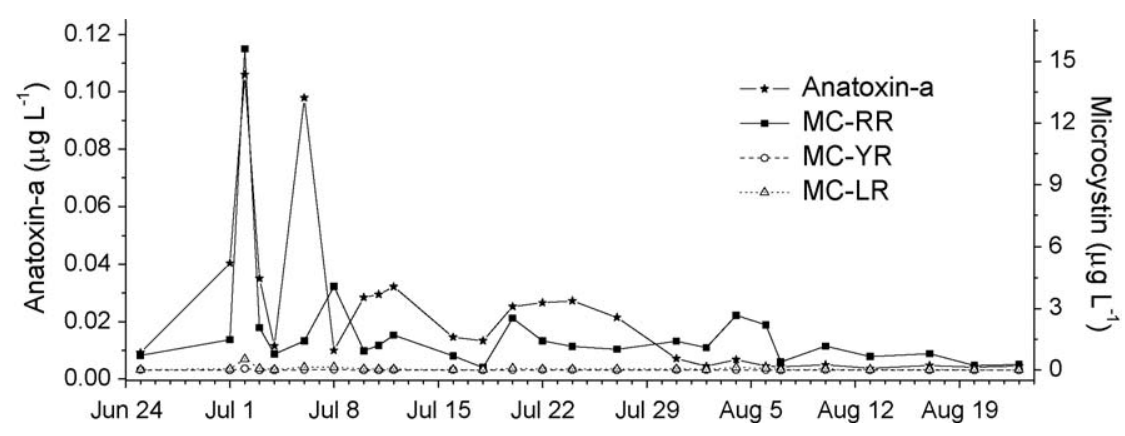

Fig. 7. Variations of dissolved cyanotoxins in the water intake surface layer.

The total geosmin concentration is plotted against $A$. spiroides density in Fig. 6. Geosmin concentration was very strongly correlated with cell numbers of Anabaena $\left(R^{2}=0.912\right)$, further demonstrating that geosmin was produced mainly by $A$. spiroides. In addition recent molecular analysis work using the method of Steven et al. (2008) has confirmed that the gene responsible for geosmin synthesis was found in the preserved field samples collected from Yanghe Reservoir (unpublished). Based upon this correlation the average geosmin cell quota for $A$. spiroides was about $0.1 \mathrm{pg} \mathrm{cell}^{-1}$, which was 10 times higher than $0.01 \mathrm{pg} \mathrm{cell}^{-1}$ that was reported in an Australian bloom associated with Anabaena sp. (Jones and Korth, 1995). In a study of the dynamics of odor compounds in the pilot experimental area of Lake Dianchi, southern China (Li L. et al., 2007; Li W. et al., 2007), correlations between particulate geosmin and the biomass of Anabaena were found. But the maximum geosmin concentration was only $10 \mathrm{ng} \mathrm{L}^{-1}$.

It should be noted that the concentration of geosmin dropped dramatically from the peak value of $7100 \mathrm{ng} \mathrm{L}^{-1}$ on 3 July to as low as $1080 \mathrm{ng} \mathrm{L}^{-1}$ on 4 July which was associated with the disappearance of $A$. spiroides. A range of factors can be important for the loss of geosmin in natural waters including biodegradation and volatilization (Lin et al., 2007). Some gram-negative (Hoefel et al., 2006) and gram-positive (Saadoun and el-Migdadi, 1998) bacteria, Pseudomonas sp., Alphaproteobacterium sp., Sphingomonas sp. (Ho et al., 2007) were reported to be involved in the biodegradation of geosmin. A population of Pseudomonas sp. and Sphingomonas sp. has been identified in Yanghe Reservoir water by molecular analysis techniques (unpublished data). The reason for the sudden disappearance of geosmin in the case of Yanghe Reservoir, however, requires further investigation.

Some samples were analyzed for both dissolved and total geosmin which includes the intracellular content for selected dates throughout the investigation (Fig. 5). In the conventional water treatment process the intracellular geosmin is readily removed together with the algal cells in the coagulation and flocculation step (Chow et al., 1999). As shown in Fig. 5, in the Yanghe Reservoir case, $85-97 \%$ of the total geosmin was intracellular, which means that less than $15 \%$ of the geosmin was present in dissolved form.
With such a high intracellular geosmin concentration, special care should be taken to prevent geosmin from being released from cells within the water treatment process. The waterworks at Qinhuangdao City stopped prechlorination during the period, which was very important to prevent $A$. spiroides cells from being broken up or lysed by chlorine. On 3 July, the total geosmin was $7100 \mathrm{ng} \mathrm{L}^{-1}$, and the dissolved geosmin was only $473 \mathrm{ng} \mathrm{L}^{-1}$. The water treatment system was able to successfully control geosmin in drinking water to below $10 \mathrm{ng} \mathrm{L}^{-1}$ by addition of powdered activated carbon (PAC) into the source-water intake and the coagulation tank in succession with a total PAC dose of $80 \mathrm{mg} \mathrm{L}^{-1}$.

\subsection{Cyanotoxins}

Variations of cyanotoxins in water intake over the period 25 June-24 August are shown in Figs. 7 and 8. All of the four cyanotoxins were detected, and most of cyanotoxins were located within the cells, indicating that appropriate treatment was required to prevent cells from being disrupted (Watanabe et al., 1992; Kenefick et al., 1993; Daly et al., 2007; Sakai et al., 2007). The maximum concentrations found for the four individual cyanotoxins were: dissolved cyanotoxins: MC-RR $1.56 \mu \mathrm{g} \mathrm{L}^{-1}$, MC-YR $0.066 \mu \mathrm{g} \mathrm{L}^{-1}, \quad$ MC-LR $0.544 \mu \mathrm{g} \mathrm{L}^{-1}$, anatoxin-a $0.106 \mu \mathrm{g} \mathrm{L}^{-1}$; intracellular cyanotoxins: MC-RR $70.1 \mu \mathrm{g} \mathrm{L}^{-1}$, MC-YR $3.76 \mu \mathrm{g} \mathrm{L}^{-1}$, MC-LR $24.6 \mu \mathrm{g} \mathrm{L}^{-1}$, anatoxin-a $0.184 \mu \mathrm{g} \mathrm{L}^{-1}$. These values occurred on 2 July, the day which coincided with the maximum total cyanobacterial density $\left(81,000\right.$ cells $\left.\mathrm{mL}^{-1}\right)$, whereas the maximum Microcystis spp. density $\left(28,000\right.$ cells $\left.\mathrm{mL}^{-1}\right)$ occurred on 30 June. It was clear that MC-RR was the dominant cyanotoxin, followed by MC-LR, while MC-YR and anatoxin-a were at a significantly lower level. More than $90 \%$ of cyanotoxins were intracellular or cell-bound during the cyanobacterial bloom period, except for MC-RR. For MC$\mathrm{RR}$, the intracellular ratio was in a wide range between 15\% and 95\% and was related to the abundance and concentration of Microcystis spp. and the stage of the bloom over the period of the study. For example the intracellular MC-RR ratio was $95 \%$ on 25 June (Microcystis spp.: 18,000 cells $\mathrm{mL}^{-1}$ ) but had fallen to $15 \%$ on 13 July (Microcystis spp.: 2000 cells $\mathrm{mL}^{-1}$ ). The reason proposed for this

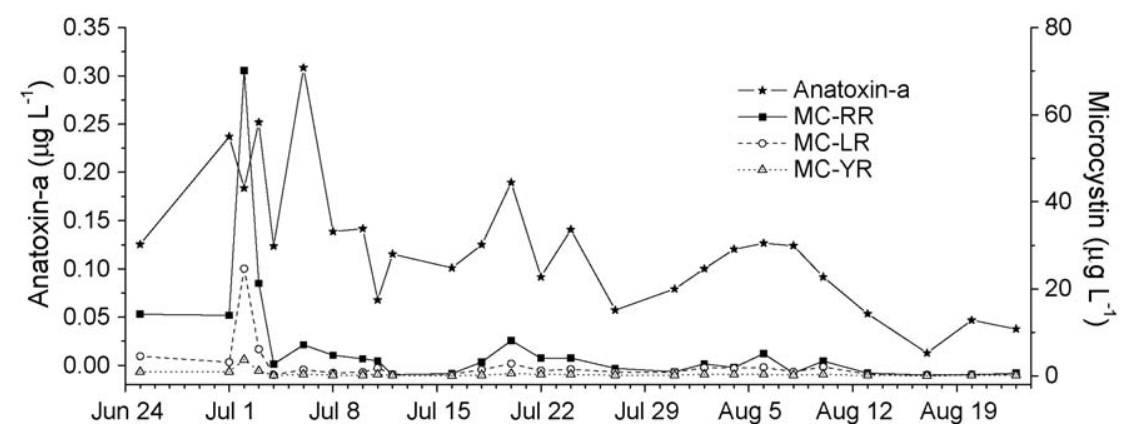

Fig. 8. Variations of intracellular cyanotoxins in the water intake surface layer. 
Table 2

Parameters from correlation analysis of cyanotoxin concentrations and cyanobacterial cell numbers ( $\mathrm{pg}$ toxin cell ${ }^{-1}$ ).

\begin{tabular}{|c|c|c|c|c|c|}
\hline & $\mathrm{MC}_{\mathrm{s}}-$ Microcystis & MC-RR-Microcystis & MC-YR-Microcystis & MC-LR-Microcystis & Anatoxin-a-Anabaena \\
\hline \multicolumn{6}{|l|}{ Total toxins } \\
\hline Slope & 1.24 & 0.973 & 0.053 & 0.215 & 0.0058 \\
\hline Stand error & 0.159 & 0.117 & 0.0065 & 0.0408 & 0.0009 \\
\hline Adj. $R^{2}$ & 0.714 & 0.738 & 0.727 & 0.527 & 0.572 \\
\hline \multicolumn{6}{|c|}{ Intracellular toxins } \\
\hline Slope & 1.08 & 0.790 & 0.054 & 0.234 & 0.0046 \\
\hline Stand error & 0.089 & 0.065 & 0.004 & 0.024 & 0.0009 \\
\hline Adj. $R^{2}$ & 0.852 & 0.851 & 0.882 & 0.784 & 0.507 \\
\hline
\end{tabular}

is that with the collapse of the Microcystis population after 30 June the MC-RR was released and remained in the water as free dissolved toxin into July. Cyanotoxins were correlated with cell densities of cyanobacteria for the 25 samples collected throughout the investigation as shown in Table 2 . The Adj. $R^{2}$ for the correlations between total toxins and cell numbers of corresponding cyanobacteria were $0.527-0.738$. The Adj. $R^{2}$ between intracellular cyanotoxins and the corresponding cell numbers were higher (0.507-0.882). It should be noted that the correlation between the intracellular MCs and Microcystis was relatively strong (0.7840.882), indicating that Microcystis was likely to have been responsible for the production of MCs. In addition, the Microcystis population contained non-microcystin producing $M$. wesenbergii (Xu Y. et al., 2008) which constituted between 10\% and 30\% range of total Microcystis population and the MC production of Microcystis was influenced by environmental factors and water quality. Also further work has shown that the mcy E gene responsible for microcystin synthesis was detected (Vaitomaa et al., 2003) in Microcystis but not in A. spiroides (unpublished data) in preserved field samples from Yanghe Reservoir. This suggested that the $A$. spiroides population would be likely to be unable to produce microcystin in this case. Based upon the slopes of the correlation curves the average MCs production potential per cell could be estimated to be approximately $1 \mathrm{pg}$ cell $^{-1}$ and about $80 \%$ of that was MC-RR.

To put the Yanghe Reservoir data into context, the dissolved MC concentrations were only about $1 / 3-1 / 2$ of that reported in an Anabaena bloom in Brazil (Sotero-Santos et al., 2008). Two separate studies of the seasonal variation of microcystin toxins associated with Microcystis blooms in Taihu Lake in southern China showed maximum toxin levels of $10.4 \mu \mathrm{g} \mathrm{L}^{-1}$ (Shen et al., 2003) and $15.6 \mu \mathrm{g} \mathrm{L}^{-1}$ (Xu Q. et al., 2008; Xu Y. et al. (2008). These concentrations were determined using ELISA and were calibrated to MC-LR, and compared with the toxin levels measured in Yanghe Reservoir, where the range of variants were determined and quantified.

Although MC-RR, the dominant microcystin in Yanghe Reservoir is not as toxic as MC-LR(Dittmann and Wiegand, 2006), the very high MC-RR concentration on July $2\left(70.1 \mu \mathrm{g} \mathrm{L}^{-1}\right)$ can be regarded as hazardous for water supply. Fortunately, the cyanotoxins can also readily be adsorbed by PAC as is geosmin, and the cyanotoxin concentrations in tap water derived from Yanghe Reservoir remained at a very low level during the cyanobacterial bloom period (for example on 16 July: the MC-RR $1.154 \mathrm{ng} \mathrm{L}^{-1}$, MC-YR $0.371 \mathrm{ng} \mathrm{L}^{-1}$, MC-LR $0.563 \mathrm{ng} \mathrm{L}^{-1}$, anatoxin-a not detected). This study has shown that both geosmin and cyanotoxins should be considered as a potential water quality hazards when a cyanobacterial bloom dominated by Anabaena and Microcystis occurs.

\section{Conclusions}

This study investigated the occurrence of both odor compounds and cyanotoxins monitored at high intensity during a cyanobacterial bloom in Yanghe Reservoir in north China. The bloom changed in composition with initial dominance by microcystin producing $M$. aeruginosa followed by $A$. spiroides which produced a very high concentration of geosmin (up to $7100 \mathrm{ng} \mathrm{L}^{-1}$ ) as well as the neurotoxin anatoxin-a. A. spiroides had a geosmin production potential of $0.1 \mathrm{pg} \mathrm{cell}^{-1}$, and more than 85\% geosmin was intracellular. Among the four detected cyanotoxins produced by cyanobacteria, MC-RR was the most abundant and the maximum dissolved concentration was $15.6 \mu \mathrm{g} \mathrm{L}^{-1}$. Most of cyanotoxins were located within the cells although as the bloom collapsed significant amounts of MC-RR were found free and dissolved in the water. By contrast the cell density of $A$. spiroides declined quickly after it reached the peak value, without perceptible release of geosmin and cyanotoxins. This study showed the relatively complex requirement for monitoring cyanobacterial blooms in this lake in China, where both the range of odors (e.g. geosmin) and cyanotoxins (MC-LR, $R R$, YR and anatoxin-a) can be produced in concentrations which can change rapidly over a short time along with the bloom composition. It also demonstrated that both odor compounds and cyanotoxins should be considered when a bloom dominated by Anabaena and Microcystis occurs.

\section{Acknowledgements}

This work was financially supported by the National Basic Research Program of China (2006CB403306) and the National Natural Science Foundation of China (50938007 and 50808177). Thanks for the help from Qinhuangdao Capital Water Group and Weather Bureau.[SS]

\section{References}

American Public Heath Association, Washington, D.C..

Aranda-Rodriguez, R., Kubwabo, C., Benoit, F.M., 2003. Extraction of 15 microcystins and nodularin using immunoaffinity columns. Toxicon 42, 587-599.

Beltran, E.C., Neilan, B.A., 2000. Geographical segregation of the neurotoxin-producing cyanobacterium Anabaena circinalis. Appl. Environ. Microbiol. 66, 44684474.

Bidle, K.D., Falkowski, P.G., 2004. Cell death in planktonic, photosynthetic microorganisms. Nat. Rev. Microbiol. 2, 643-655.

Chow, C.W.K., Drikas, M., House, J., Burch, M.D., Velzeboer, R.M.A., 1999. The impact of conventional water treatment processes on cells of the cyanobacterium Microcystis aeruginosa. Water Res. 33, 3253-3262.

Codd, G.A., 1995. Cyanobacterial toxins: occurrence, properties and biological significance. Water Sci. Technol. 32, 149-156.

Daly, R.I., Ho, L., Brookes, J.D., 2007. Effect of chlorination on Microcystis aeruginosa cell integrity and subsequent microcystin release and degradation. Environ. Sci. Technol. 41, 4447-4453.

Dittmann, E., Wiegand, C., 2006. Cyanobacterial toxins-occurrence, biosynthesis and impact on human affairs. Mol. Nutr. Food Res. 50, 7-17.

Dokulil, M.T., Teubner, K., 2000. Cyanobacterial dominance in lakes. Hydrobiologia 438, 1-12.

Duy, T., Lam, P., Shaw, G., Connell, D., 2000. Toxicology and risk assessment of freshwater cyanobacterial (blue-green algal) toxins in water. Rev. Environ. Contam. Toxicol. 163, 113-186.

Gladyshev, M.I., Sushchik, N.N., Kalachova, G.S., Shchur, L.A., 1998. The effect of algal blooms on the disappearance of phenol in a small forest pond. Water Res. 32, 2769-2775. 
Haider, S., Naithani, V., Viswanathan, P.N., Kakkar, P., 2003. Cyanobacterial toxins: a growing environmental concern. Chemosphere 52, 1-21.

Hayes, K.P., Burch, M.D., 1989. Odorous compounds associated with algal blooms in South Australian waters. Water Res. 23, 115-121.

Ho, L., Hoefel, D., Bock, F., Saint, C.P., Newcombe, G., 2007. Biodegradation rates of 2methylisoborneol (MIB) and geosmin through sand filters and in bioreactors. Chemosphere 66, 2210-2218.

Hoefel, D., Ho, L., Aunkofer, W., Monis, P.T., Keegan, A., Newcombe, G., Saint, C.P., 2006. Cooperative biodegradation of geosmin by a consortium comprising three gram-negative bacteria isolated from the biofilm of a sand filter column. Lett. Appl. Microbiol. 43, 417-423.

Hötzel, G., Croome, R., 1999. A Phytoplankton Methods Manual for Australian Freshwaters. Land and Water Resources Research and Development Corporation.

Izaguirre, G., Hwang, C.J., Krasner, S.W., McGuire, M.J., 1982. Geosmin and 2methylisoborneol from cyanobacteria in three water supply systems. Appl. Environ. Microbiol. 43, 708-714.

Jones, G.J., Korth, W., 1995. In situ production of volatile odor compounds by river and reservoir phytoplankton populations in Australia. Water Sci. Technol. 31, 145-151.

Kenefick, S.L., Hrudey, S.E., Peterson, H.G., Prepas, E.E., 1993. Toxin release from Microcystis aeruginosa after chemical treatment. Water Sci. Technol. 27, 433-440.

Khan, F., Ansari, A., 2005. Eutrophication: an ecological vision. Bot. Rev. 71, 449482.

Li, L., Wan, N., Gan, N.Q., Xia, B.D., Song, L.R., 2007. Annual dynamics and origins of the odorous compounds in the pilot experimental area of Lake Dianchi, China. Water Sci. Technol. 55, 43-50.

Li, W., Cai, J., Pang, Y., Xiao, X., 2007. Eutrophication assessment of Yanghe Reservoir and its control measures. Water Resour. Prot. 23, 16-19 (in Chinese).

Lin, T.-F., Hobson, P., Burch, M., Chen, Y.-M., 2007. Modeling the mass balance of two cyanobacterial odorants in reservoirs. In: Proceedings of 3rd International Conference on Sustainable Water Environment: Integrated Water Resources Management-New Steps, Sapporo, Japan, pp. 24-25.

Liang, C., Wang, D., Yang, M., Sun, W., Zhang, S., 2005. Removal of eathy-must odorants in drinking water by powdered activated carbon. J. Environ. Sci. Health A 40, 767-778.

Moore, R.E., Ohtani, I., Moore, B.S., Dekoning, C.B., Yoshida, W.Y., Runnegar, M.T.C., Carmichael, W.W., 1993. Cyanobacterial toxins. Gazz. Chim. Ital. 123, 329-336.

Neilan, B.A., Hawkins, P.R., Cox, P.T., Goodman, A.E., 1994. Towards a molecular taxonomy for the bloom-forming cyanobacteria. Aust. J. Mar. Freshwater Res. 45, 869-873.

Osswald, J., Rellán, S., Gago, A., Vasconcelos, V., 2007. Toxicology and detection methods of the alkaloid neurotoxin produced by cyanobacteria, anatoxin-a. Environ. Int. 33, 1070-1089.

Paerl, H.W., Fulton 3rd, R.S., Moisander, P.H., Dyble, J., 2001. Harmful freshwater algal blooms, with an emphasis on cyanobacteria. Sci. World J. 1, 76-113.

Pawlik-Skowronska, B., Skowronski, T., Pirszel, J., Adamczyk, A., 2004. Relationship between cyanobacterial bloom composition and anatoxin-A and microcystin occurrence in the eutrophic dam reservoir (SE Poland). Pol. J. Ecol. 52, 479-490.

Saadoun, I., el-Migdadi, F., 1998. Degradation of geosmin-like compounds by selected species of gram-positive bacteria. Lett. Appl. Microbiol. 26, 98-100.

Saadoun, I., Schrader, K.K., Blevins, W.T., 2001. Identification of geosmin as a volatile metabolite of Anabaena sp. J. Basic Microbiol. 41, 51-55.

Sakai, H., Oguma, K., Katayama, H., Ohgaki, S., 2007. Effects of low or mediumpressure UV irradiation on the release of intracellular microcystin. Water Res. $41,3458-3464$.
Sedmak, B., Kosi, G., 1998. The role of microcystins in heavy cyanobacterial bloom formation. J. Plankton Res. 20, 691-708.

Shen, P.P., Shi, Q., Hua, Z.C., Kong, F.X., Wang, Z.G., Zhuang, S.X., Chen, D.C., 2003. Analysis of microcystins in cyanobacteria blooms and surface water samples from Meiliang Bay, Taihu Lake, China. Environ. Int. 29, 641-647.

Sotero-Santos, R.B., Carvalho, E.G., Dellamano-Oliveira, M.J., Rocha, O., 2008. Occurrence and toxicity of an Anabaena bloom in a tropical reservoir (Southeast Brazil). Harmful Algae 7, 590-598.

Steven, G., Jiang, J., Saint, C.P., Cane, D.E., Monis, P.T., 2008. Isolation and characterization of the gene associated with geosmin production in cyanobacteria. Environ. Sci. Technol. 42, 8027-8032.

Tsujimura, S., Okubo, T., 2003. Development of Anabaena blooms in a small reservoir with dense sediment akinete population, with special reference to temperature and irradiance. J. Plankton Res. 25, 1059-1067.

Vaitomaa, J., Rantala, A., Halinen, K., Rouhiainen, L., Tallberg, P., Mokelke, L., Sivonen, K., 2003. Quantitative real-time PCR for determination of microcystin synthetase e copy numbers for Microcystis and Anabaena in lakes. Appl. Environ. Microbiol. 69, 7289-7297.

van Apeldoorn, M.E., van Egmond, H.P., Speijers, G.J.A., Bakker, G.J.I., 2007. Toxins of cyanobacteria. Mol. Nutr. Food Res. 51, 7-60.

Van der Ploeg, M., Tucke, C.S.r., Boyd, C.E., 1992. Geosmin and 2-methyisoborneol production by cyanobacteria in fish ponds in the southeastern United States. Water Sci. Technol. 25, 283-290.

Veldhuis, M., Brussaard, C., 2006. Ecol. Harmful Algae 153-162.

Velzeboer, R.M.A., Baker, P., Rositano, J., Heresztyn, T., Codd, G.A., Raggett, S., 2000 Geographical patterns of occurrence and composition of saxitoxins in the cyanobacterial genus Anabaena (Nostocales, Cyanophyta) in Australia. Phycologia 39, 395-407.

Wang, S.H., Dzialowski, A.R., Meyer, J.O., de Noyelles, F., Lim, N.C., Spotts, W.W. Huggins, D.G., 2005. Relationships between cyanobacterial production and the physical and chemical properties of a Midwestern Reservoir, USA. Hydrobiologia 541, 29-43.

Watanabe, M.F., Tsuji, K., Watanabe, Y., Harada, K., Suzuki, M., 1992. Release of heptapeptide toxin (microcystin) during the decomposition process of Microcystis aeruginosa. Nat. Toxins $1,48-53$.

Watson, S.B., 2004. Aquatic taste and odor: a primary signal of drinking-water integrity. J. Toxicol. Environ. Health A 67, 1779-1795.

Watson, S.B., Charlton, M., Rao, Y.R., Howell, T., Ridal, J., Brownlee, B., Marvin, C., Millard, S., 2007. Off flavours in large waterbodies: physics, chemistry and biology in synchrony. Water Sci. Technol. 55, 1-8.

Wnorowski, A.U., Scott, W.E., 1992. Incidence of off-flavors in South-African surface waters. Water Sci. Technol. 25, 225-232.

Xie, L., Xie, P., Li, S., Tang, H., Liu, H., 2003. The low TN:TP ratio, a cause or a result of Microcystis blooms? Water Res. 37, 2073-2080.

Xu, Q., Chen, W., Gao, G., 2008. Seasonal variations in microcystin concentrations in Lake Taihu, China. Environ. Monit. Assess. 145, 75-79.

Xu, Y., Wu, Z., Yu, B., Peng, X., Yu, G., Wei, Z., Wang, G., Li, R., 2008. Non-microcystin producing Microcystis wesenbergii (Komārek) Komārek (Cyanobacteria) representing a main waterbloom-forming species in Chinese waters. Environ. Pollut. $156,162-167$.

Yoshinaga, I., Hitomi, T., Miura, A., Shiratani, E., Miyazaki, T., 2006. Cyanobacterium Microcystis bloom in a eutrophicated regulating reservoir. Jpn. Agric. Res. Q 40, 283-289.

Zhang, Y., Yang, M., Li, Z., Zhang, J., Guo, Z., 2005. Determination of microcystins RR, YR and LR in water by high performance liquid chromatography-electrospray ionization mass spectrometry. China Water Wastewater 21, 94-96 (in Chinese). 